\title{
Kronika \\ Katedry Nauk Historycznoprawnych \\ Wydziału Prawa Uniwersytetu w Białymstoku (lata 2005-2006)
}

\section{Publikacje}

W 2005 r. ukazały się dwie książki Adama Lityńskiego: ogólnopolski podręcznik Historia prawa Polski Ludowej (wydawnictwo Lexis Nexis) oraz Od Rzeczypospolitej szlacheckiej do Rzeczypospolitej ludowej. Studia z dziejów prawa karnego (Śląskie Wydawnictwa Naukowe). Natomiast w 2006 r. ukazała się monografia Marcina Łysko Prokuratorski nadzór ogólny w Polsce w latach 1950-1967 (wydawnictwo Temida 2).

Spośród kilkunastu publikacji autorstwa pracowników Katedry w ogólnopolskich czasopismach zostały zamieszczone następujące artykuły: na łamach „Czasopisma Prawno-Historycznego" publikowali Adam Lityński (O prawie cywilnym i karnym jako elementach praworządności „spustoszonego stulecia” uwag kilka, CPH 2005, t. LVII, z. 1), Piotr Fiedorczyk (Kościół katolicki i opozycja polityczna wobec unifikacji osobowego prawa matżeńskiego w 1945 r., CPH 2004, t. LVI, z. 1 oraz artykuł recenzyjny O dziejach prawa socjalistycznej Czechosłowacji (Vyvoj prava c Ceskoslovensku v letach 1945-1989. Sbornik prispevku), red. K. Maly i L. Soukup, Praha 2004, CPH 2006, t. LVIII, z. 2) i Marcin Łysko (Prokuratorski nadzór ogólny w Polsce w latach 1950-1967, CPH 2005, t. LVII, z.2).Piotr Fiedorczykzamieściłswoje artykuływ „Kwartalniku Prawa Prywatnego” (Prawo opiekuńcze w pracach nad unifikacja prawa cywilnego w 1945-46 r., KPP 2005, z. 3) oraz w „Kwartalniku Prawa Publicznego” (Organizacja i obsada kadrowa delegatur Komisji Specjalnej do Walki z Nadużyciami i Szkodnictwem Gospodarczym, KPP 2004, nr 3). Artykuł Piotra Fiedorczyka Historia de la unificacion y codificación del derecho familiar en Polonia en el siglo XX został opublikowany w hiszpańskim czasopiśmie prawniczym „Anales de Derecho”, Pamplona 2004, nr 5. Autor ten publikował także na łamach rosyjskiego czasopisma "Siemiejnoje i Żiliszcznoje Prawo", zamieszczając w numerze 2 z 2006 r. artykuł Istoria razwitia siemiejnowo prawa Polszy w XX wiekie. Począwszy od 2002 r. regularnie ukazują się zeszyty zakładowe „Miscellanea historico-iuridica”, obecnie trwają prace nad kolejnym zeszytem. 


\section{UDZIAE W KONFERENCJACH NAUKOWYCH}

\section{Konferencje krajowe}

Pracownicy Katedry brali udział w krajowych i zagranicznych konferencjach naukowych, wygłaszając w ich trakcie referaty. Cały zespół Katedry był obecny na Ogólnopolskim Zjeździe Historyków Państwa i Prawa w Lublinie „Cuius regio eius religio” (wrzesień 2006). Adam Lityński przewodniczył obradom sesji plenarnej, podczas której wygłosił referat $O$ (nie)praworząności socjalistycznej $w$ Polsce Ludowej. Natomiast w ramach poszczególnych sekcji swoje referaty zaprezentowali pozostali pracownicy Zakładu Historii Państwa i Prawa:

- Piotr Fiedorczyk - Unifikacja $i$ kodyfikacja prawa rodzinnego na tle stosunków pomiędzy państwem a Kościołem katolickim w Polsce (1944-1964);

- Mariusz Mohyluk - Poglady Kościoła katolickiego w II RP na temat prawa radzieckiego;

- Ireneusz Grat - Prawo do wolności sumienia w kontekście prawa natury;

- Marcin Łysko - Działalność duszpasterska Kościoła katolickiego w świetle prawodawstwa i praktyki władz okresu gomutkowskiego;

- Karol Kuźmicz, Filozofia religii Immanuela Kanta jako przyczyna jego sporu zwładza.

Pracownicy Zakładu Prawa Rzymskiego i Kanonicznego uczestniczyli w Ogólnopolskim Zjeździe Katedr Prawa Rzymskiego w Suchej Beskidzkiej (czerwiec 2005), gdzie referat pt. Rzymska terminologia stosowana na określenie narzędzi stosowanych podczas chłosty wygłosił Piotr Kołodko. Podczas Spotkania naukowo-szkoleniowego romanistów w Ostródzie (czerwiec 2006) referaty zaprezentowali Piotr Kołodko (Chłosta jako kara w rzymskim wojskowym prawie karnym) oraz Krzysztof Szczygielski (Konkubinat a zasady porządku i moralności publicznej w starożytnym Rzymie).

W zorganizowanej przez działające na Wydziale Prawa UwB Studenckie Koło Naukowe Filozofii Prawa (opiekun naukowy Karol Kuźmicz) oraz Miłośników Prawa i Kultury Antycznej (opiekun naukowy Piotr Niczyporuk) konferencji "Jednostka a państwo" (Białystok, maj 2005) brali udział i wygłosili referaty:

- Piotr Niczyporuk - Dopuszczalność przerywania ciąży w prawie rzymskim;

- Mariusz Mohyluk - Jednostka w „trybach" radzieckiego prawa karnego;

- Ireneusz Grat - Problem atomizacji społeczeństwa w pogląach Władysława Leopolda Jaworskiego;

- Marcin Łysko - Jednostka jako podmiot działalności prokuratorskiego nadzoru ogólnego w Polsce Ludowej; 
- Karol Kuźmicz - Jednostka w kantowskim „państwie celów”;

- Piotr Kołodko - Chłosta jako kara zastępcza w prawie rzymskim.

Kolejna konferencja, zorganizowana przez wspomniane koła naukowe, odbyła się w Białymstoku w listopadzie 2006 r. nosiła tytuł: „Prawo a sumienie”. W jej trakcie pracownicy Katedry zaprezentowali następujące referaty:

- Karol Kuźmicz - Problem „więźniów sumienia” w epoce globalizacji;

- Mariusz Mohyluk - Bierdiajewa myśli o sumieniu;

- Ireneusz Grat - Sumienie zbiorowe w systemach totalitarnych.

Ponadto poszczególni pracownicy wygłosili referaty, biorąc udział w następujących konferencjach:

- Adam Lityński - ogólnopolska konferencja „W pięćsetlecie konstytucji Nihil novi. Z dziejów stanowienia prawa w Polsce", która miała miejsce w grudniu 2005 r. na Wydziale Prawa Wyższej Szkoły Handlu i Prawa im. R. Lazarskiego w Warszawie. Referat: Dwie transformacje prawa $w$ Polsce XX wieku. Koncepcje i ich realizacja;

- Adam Lityński - konferencja zorganizowana przez Wyższą Szkołę Zarządzania i Nauk Społecznych w Tychach w grudniu 2005 r. pt. „Początki Państwa Polskiego po I wojnie światowej: budowa systemu ustrojowego oraz polskiego porządku prawnego". Referat: Ku własnemu prawu we własnym państwie. Tworzenie prawa sądowego w II RP;

- Adam Lityński - Kongres Badaczy Osiemnastego Wieku we Wrocławiu w październiku 2006 r.pt. „WiekXVIII, polityka-kultura-edukacja”. Referat: Wolność, równość, praworządność. Oświeceniowe korzenie wspótczesnego prawa karnego i cywilnego;

- Piotr Fiedorczyk - Konferencja zorganizowana przez oddział IPN w Białymstoku w październiku 2006 r. pt. „Polska północno-wschodnia w okresie stalinizmu - spojrzenie z perspektywy półwiecza”. Referat: Organizacja i obsada kadrowa białostockiej Delegatury Komisji Specjalnej do Walki $z$ Nadużyciami i Szkodnictwem Gospodarczym (1946$-1954)$;

- Karol Kuźmicz - Konferencja „Ideowość w polityce” (Kuźnica na Helu, październik 2006). Wystąpienie: Od ideowości do szaleństwa.

- Ireneusz Grat - sesja popularnonaukowa zorganizowana $\mathrm{z}$ okazji 25-lecia pracy społecznej białostockiego Oddziału Towarzystwa Opieki nad Majdankiem w październiku 2005 r. pt. „Człowiek przeciwko człowiekowi. Dwudziestowieczne ludobójstwo systemów totalitarnych". Referat: Doktrynalno-prawne uwarunkowania hitlerowskiej i stalinowskiej machiny ludobójstwa. 
Referat ten został następnie zamieszczony w materiałach pokonferencyjnych wydanych w formie książki zbiorowej pt. „Człowiek przeciwko człowiekowi. Dwudziestowieczne ludobójstwo systemów totalitarnych”. Redaktorem naukowym tej pozycji jest dr Ireneusz Grat, a recenzentem pracownik Katedry dr hab. Jarosław Wołkonowski. Prezentacji książki dr Grat dokonał w grudniu 2006 r. na Wydziale Prawa UwB, po prezentacji dr hab. Wołkonowski wystąpił z wykładem pt. „Wileńskie Ponary - największe miejsce kaźni na Kresach Wschodnich".

\section{Konferencje zagraniczne}

W konferencjach zagranicznych poświęconych problematyce prawa rodzinnego uczestniczył Piotr Fiedorczyk. W lipcu 2005 r. brał udział w XII World Congress of International Society of Family Law (ISFL), który miał miejsce w Salt Lake City; temat kongresu brzmiał: „Family Law - Balancing Interests and Pursuing Priorities”. Wystąpiłtamzreferatem pt. Family Lawin Communist Poland; between Soviet Patterns and European Legal Tradition. Podczas zorganizowanej w Moskwie (grudzień 2005) przez Dumę Państwową i Rosyjską Akademię Prawa Ministerstwa Sprawiedliwości Rosyjskiej Federacji konferencji „Siemja i pravo (k 10-letiju prinjatija semiejnogo kodieksa Rossijskoj Fiedieracji)" wygłosił referat dotyczący wpływów prawa radzieckiego na polskie prawo rodzinne po II wojnie światowej. Na 36. Kongresie Niemieckich Historyków Prawa w Halle (wrzesień 2006) zaprezentował referat pt. Reconciliation with the Communist Past: the Polish Way. Podczas odbywającej się w Wiedniu w październiku 2006 roku konferencji „Developments in Marriage and Marital Law in Central and Eastern Europe: Reports, Prospects and Analysis" Piotr Fiedorczyk wystąpił $\mathrm{z}$ referatem Revisons of Family Law in Poland after 1989 with Particular Focus on Property Relations Between Spouses.

Ponadto w maju 2006 r. prowadził w języku angielskim wykłady z historii prawa $\mathrm{w}$ ramach programu Socrates/Erasmus w Institute d'Etudes Politiques w Rennes.

Piotr Niczyporuk uczestniczył w konferencji „Diritto romano pubblico e privato: lesperienza plurisecolare dello sviluppo del diritto europeo", która miała miejsce w Moskwie w czerwcu 2006 r. Wygłosił tam referat Bankowaja diejatelność $w$ drewnem Rime, a direktywy Ewropejskowo Sojuza. Z kolei podczas międzynarodowej konferencji „Psucie pieniądza - Białoruś - Litwa - Łotwa - Ukraina" (Augustów, wrzesień 2006) wystąpił z referatem Nummularii jako strażnicy jakości monety w starożytnym Rzymie. 


\section{Sprawy kadrowe}

Począwszy od listopada 2006 r. pracownikiem Zakładu Prawa Rzymskiego i Kanonicznego został prof. dr hab. Jan Zabłocki.

W czerwcu 2006 r. miała miejsce publiczna obrona pracy doktorskiej Krzysztofa Szczygielskiego Konkubinat $w$ prawie kanonicznym Kościoła Katolickiego (studium historyczno-prawne) napisanej w Zakładzie Prawa Rzymskiego i Kanonicznego pod kierunkiem ks. prof. dr. hab. Floriana Lempy. Recenzentami w przewodzie byli prof. dr hab. Bronisław Sitek oraz prof. dr hab. Mieczysław Goettel. Rada Wydziału Prawa UwB jednomyślnie przyznała Krzysztofowi Szczygielskiemu tytuł doktora nauk prawnych.

Do grona badaczy prawa Polski Ludowej w naszej Katedrze dołączyła doktorantka Diana Maksimiuk, która jest także absolwentką Wydziału Historyczno-Socjologicznego UwB. Jej praca dyplomowa Król i instytucja monarchy a sejmiki za panowania Zygmunta III Wazy, napisana pod kierunkiem prof. dr hab. Ewy Dubas-Urwanowicz, uzyskała I nagrodę w III edycji konkursu organizowanego przez Fundację Aurea Demokratia w kategorii prac magisterskich dotyczących historii polskiego parlamentaryzmu od jego zarania do końca I Rzeczypospolitej. 